\author{
MARIASCHNITZER, \\ Uzhhorod National University (Uzhhorod, Ukraine) \\ e-mail: mariya.shnitser@uzhnu.edu.ua,ORCID 0000-0003-2781-3928
}

\title{
METAPHOR AS A DEVELOPMENT FACTOR OF THE NETWORK SOCIETY
}

The formation of the methodological apparatus of network theory has been shown and the role of metaphor in the network society has been investigated to identify changes in reality and the emergence of new knowledge or a new variant of knowledge. It has been determined that thanks to metaphors, the paradigm of description of contemporary society has changed, which is now characterized as "network" or "web", "flowing", "dynamic", "uneven" etc. The most famous attempts of such a description are the concept of new sociality by Z. Bauman and the actor-network theory by $B$. Latour. The latter allows considering the metaphor at the epistemological level of knowledge, i.e. in the processes of social construction. In this case, metaphors are used to build various kinds of metatheories that combine ways of substantiating and structuring knowledge about society, as well as determine the logical correlation of the main elements of analysis. An analysis of R. Haeussling's network concept is given as an illustration of such possibilities of metaphor.

Keywords: network theory; network society; metaphor; metatheory.

\section{Introduction}

Today, the network is considered the dominant paradigm of worldview. We are talking about social networks, network society, knowledge network, network management, network culture etc. All these characteristics come from the conceptualizations of reality related to both advances in the natural sciences and the informational nature of the changes taking place in the very structure of society, which is understood now as a network of interaction and communication, and human is understood as relatively free and autonomous individual who falls, however, under the influence of new meanings generated in contemporary culture. In this regard, the social sciences are raising the question of the rational use of the capabilities of revolutionary network technologies and the development of tools that allow such rationalization. Researchers who are considered "pioneers of the network approach" - E. Durkheim, G. Simmel, G. Deleuze and F. Guattari - also used content and concepts more understandable to the scientific community to mark a new understanding of social reality for describing a new approach to understanding society and social. For example, E. Durkheim in his "The Elementary Forms of the Religious Life" (1954) discusses rituals that allow the individual to navigate in the social space and "these 'collective representations' settle in the human mind and act as gyroscopes that guide people to certain types of interaction and keep them from other types" (Durkheim, 1954: 230-231). Developing this thesis by Durkheim, R. Collins derives the concept of a network of ritual interactions, because the network does not perceive rigidity and is characterized by variability (Collins, 2009). G. Simmel, postulating the question of the ontological principles of society, concludes that the social is constituted by the subjects, their relations and interactions. Society is understood by Simmel as dynamic, because it is a process of human interaction (Simmel, 1996 . 513).

The phenomenon of the network was comprehended deeply in the work "A Thousand Plateaus" by G. Deleuze and F. Guattari. Using the rhizome metaphor, they described in detail the methodology and ontology of the network. Deleuze and Guattari formulated the basic characteristics of a network organization, such as heterogeneity, multiplicity, simultaneity of localized organizations, and continuity of movement in an effort to go beyond their own boundaries. Taking the relativity of the rhizome as a fact, the authors of "A Thousand Plateaus" focus on the structure of the network, its characteristics and properties, because "in the set there is neither a subject nor an object, there is only a definition, size, measurement" (Deleuze, Guattari, 2010: 14). The rhizome is inherently complete, impersonal and variable, "it has neither a beginning nor an end, but always the middle, from which it grows and flows over the edge" (Deleuze, Guattari, 2010: 377).

Thus, in the late 1980s in France, the fundamental foundations of network theory, which today has become a methodological apparatus, were laid. It is at this time that the network begins to take the form of a concept rather than being used as a metaphor. Investigating the metaphorical nature of the network, V.V. Vasilkova believes that metaphor can act as a "cognitive mechanism capable of producing new figurative models using a flexible semantic shift of 'frame' and 'focus', which later create new theoretical positions" (Vasilkova, 2012). From this moment, we can talk about metaphor as an indicator of the transformation of reality and the formation of new knowledge, which marks the search for a new understanding and the birth of another ontology.

The purpose of this article is to study the role of metaphor in network society and its importance in the formation (provoking) of new types of knowledge.

\section{Methods}

The methodological basis of our study is the concept of R. Collins on the influence of the network structure of relations between intellectuals on the construction of ideas. 
In his "Sociology of Philosophies: A Global Theory of Intellectual Change", he argues that the encounters of individuals in social interaction give rise to or cause certain interactive rituals. An interactive ritual requires at least two people focusing on one object, event, or action, and sharing a common mood or emotion, which increases or accumulates mutual focus. As a result, participants' relationships are symbolized by everything that has become the focus of attention in social communication (Collins calls it ritual interaction), and over time, when people use these symbols in conversation or thinking, it reminds them of group affiliation. In addition, participants in such interactive rituals, according to Collins, are filled with emotional energy in proportion to the intensity of interaction, as well as with a stock of emotionally charged symbols - cultural capital (Collins, 2009: 69-72). The second part of his hypothesis about emotional energy and cultural capital is especially valuable for our study, because, based on it, we can, in our opinion, explain the cognitive potential of metaphor in the transformation and development of reality.

\section{Result and Discussion}

At the stage of formation of new knowledge, when new ideas are verbalized and new linguistic means are needed for adequate interpretation of the received information and its introduction into the general system of knowledge, a new (invariant) conceptual system with new semantic space and new developed meanings is built with the help of metaphor. G. Lakoff and M. Johnson call this process the basis of categorization: certain properties of an object or social fact are emphasized, highlighted, and others, on the contrary, are suppressed. And it is metaphor, according to these authors, that sets the right focus of categorization (Lakoff, Johnson. 2004: 43).

In addition, with the help of metaphor, thought moves freely from one semantic space to another, while the specific focus of attention on certain properties of the object or fact is preserved. Thus, by connecting different semantic concepts (previously logically incompatible), it combines different layers of human experience, creates procedures for processing different structures of knowledge and provides access to an abstract level of thinking (Lakoff, Johnson. 2004).

The famous historian of science F. Capra presents the whole history of science as a change in basic metaphors, i.e. as a change in the types of substantiation of knowledge (Capra, 2002). He writes that "network thinking" has changed not only our view on nature, but also our way of describing scientific knowledge. Thus, the researcher shows that for several centuries, scientists and philosophers have used the metaphor of the building in relation to knowledge, with the numerous architectural metaphors arising from it. It has become customary to talk about fundamental laws, fundamental principles, the basic building blocks or bricks, that the building of science must be built on a secure foundation. When significant scientific revolutions took place, it was perceived as if the fundamentals of science and its entire foundation were shifting. This metaphor corresponded to the mechanistic worldview, according to which the world is a collection of objects. They interact with each other as elements of the system, and therefore there is a relationship between them, but this relationship is secondary.

Thanks to the discoveries of quantum physics, it became clear that "there are no pieces at all". What we call a piece is just a pattern in the indivisible web of relationships. Therefore, the transition from pieces to the whole can also be considered as a transition from objects to relationship. (In studies of recent decades, this worldview is most adequately represented in the theory of self-organization of dissipative structures and the synergetic complexity theory.) (Capra, 2002).

In contemporary science, as Capra points out, objects themselves are networks of relationships included in larger networks. Now the relations are primary, and the boundaries of visible patterns ("objects") are secondary. Thus, the living world appears in the form of a network of relationships, and the metaphor of the network replaces the metaphor of the building. "The material universe is seen as a dynamic web of interrelated events. None of the properties of any part of this web is fundamental; they all follow from the properties of the other parts, and the overall consistency of their interrelations determines the structure of the entire web" (Capra, 2002).

"A new understanding of reality requires new ways of describing it - knowledge should be an interconnected network of concepts and models, in which there are no foundations", - Capra emphasizes, noting that the idea of scientific knowledge as a network of concepts and models in which no part is more fundamental than the other was formulated in the 1970s by physicist Geoffrey Chew in the form of the so-called bootstrap theory. The philosophy of the bootstrap not only rejects the idea of the fundamental bricks of matter, but does not accept any fundamental essences at all - neither fundamental constants nor fundamental laws or equations. And as this network approach spreads in the scientific community, the idea of knowledge as a network will undoubtedly find more and more supporters (Capra, 2002).

To describe contemporary society, it is also customary to use metaphors that can serve as a logical framework for macro-sociological, societal concepts. According to V. Vasilkova, in the history of social thought, the most influential metaphor of this kind, which substantiates the stability and coherence of parts, is the metaphor of society as a whole organism, and it served as the impulse for the formation of system theory (and more broadly - system approach) in sociology, able to describe the multidimensional structure of society in its development from the position of holism (Vasilkova, 2012).

And despite the fact that the categorical patterns of description of social reality formed on this metaphorical basis still continue to work effectively in a certain cognitive zone, fixing established social ties in a situation of relative stability, a new gestalt of social worldview has been formed in social knowledge since the 1980s - the main focus is the new social ontology of "liquid modernity" and the corresponding principles of describing sociogenesis (dynamism, instability, stochasticity, constructivist role of social actors), i.e. the principles that substantiate unstable connectivity. The unifying, "umbrella" metaphor for describing these ontological phenomena of the "web of social life" (using the term by F. Capra) is the network metaphor.

The properties of the network - imbalance, dynamism and the possibility of transformation - proved to be the most promising for describing the dynamics of social structuring. One of the most famous attempts at such a description is Z. Bauman's new sociality.

The new sociality, according to Bauman, is the sociality of "weakening ties" generated by a new type of uncertainty: "Contemporary fears, anxieties and grievances are made to be suffered alone. They do not add up, do not cumulate into a 'common cause', have no specific, let alone obvious, address" (Bauman, 2008: 160). Contemporary uncertainty 
creates a powerful individualization - it does not unite people to protect common interests (as it was before), but divides them.

The very foundations of previous solidarity are violated. This is related to the fact that the use of labor power has become short-term and depends on uncertain circumstances, devoid of a solid perspective, that is, as the researcher notes, the rules of the game change too quickly and unpredictably. The place of work is now perceived not as a "common permanent residence" where a person is going to endure hardships and develop acceptable rules of coexistence, but as a "a camping site which one visits for just a few days, and may leave at any moment if the comforts on offer are not delivered or found unsatisfactory when delivered" (Bauman, 2008: 161). To characterize contemporary society, he cites, again, a metaphorical description of M. Granovetter: contemporary society is a society of "weak ties". When there are no grounds for the formation of common interests, the need and necessity of the "art of dialogue" as a manifestation of stable, longterm, strong ties, disappears. The incentive for hard and sometimes sacrificial work on preservation and development of partnership relations, long human relations is lost. The principles of "temporary coexistence" become the norm, when the rupture of relations is possible at any time and for any reason, as soon as the need or desire to continue them disappears (Bauman, 2008).

Another attribute of light contemporary capitalism, which generates a "weakening of ties", is consumerism with its intense change in consumer demands and desires. Now it makes no sense to hold on an outdated or low-quality product - you just need to find a new and improved one (easier to replace one than to keep it) (Bauman, 2008: 176). This leads not only to the total temporality of the partnership, but also to their superficiality and functionality - the sparse nature of the social network.

In addition, the metaphor of the network is, of course, a metaphor of the societal level, covering the whole set of social relations, because a social system of any level, including society as a whole, can be represented as networks. The structure of the network combines the interactions of actors at the micro and macro level of structural change, which allowed, for example, B. Latour to justify the integration potential of theoretical models of society (Latour, 2006), and it can be added that these models are also based on the network metaphor.

The general concepts of actor-network theory of B. Latour, which A. Sivokon (2016) calls one of the main approaches to the study of network society, are: hybrid, network of actors, network configuration. It should be considered in more detail how B. Latour explains the structure of contemporary society and uses the productive potential of metaphor for conceptual construction.

A research laboratory is the source of inspiration and prototype for Latour's network model. In the essay "Laboratory Life", he gives the initial definition of the network as a set of positions within which an object is essential (Latour, 2006). In subsequent essays, he proposes to understand the network as an "association of heterogeneous elements", which includes very different things social, natural, technical (people, organizations, microbes, devices, sponsors, test tubes, theorems, experimental animals, etc.) - "people" and "non-people". Latour also uses the combined term "actant" to refer to the elements of the network - any actor involved in the construction and development of the network; it is the one who got into the network, whose role in the network is somehow taken into account. It does not matter for the life of the network what elements (links) it consists of; it is important which of them will withstand the "confrontation in the test of strength": the experimental rats will die, or the sponsor will leave - for the network it has the same consequences. The art of networking is the art of connecting and holding all disparate elements together. The growth of the network is a combination of weaknesses, their testing by force and hardening, which leads to a stable combination of forces. Latour in his various works describes the life cycle of the network, the five stages of its "consolidation", the criteria for the transformation of the network (the appearance of "transition points" to a new state), etc.

Thus, without rejecting the postulate of the sociocreative function of science and technology (which was convincingly substantiated by $\mathrm{M}$. Castells in his theory of network society), Latour still does not consider them a priority. He views society through the prism of hybrids sets of complex objects capable of action. Actor-network theory rejects the idea of things as passive objects that are subordinate to a human. Latour argues that not only subjects are capable of constituting the social, artifacts are largely the objectivity of which sociality is composed. In the context of the network approach, the focus is shifted to the action itself as a social fact. The use of the very concepts of subject and object in speech becomes incorrect, and therefore they are both replaced by a more abstract concept of the actor who performs (mediates) the action.

The network of actors is a characteristic of global interaction distributed in space and time, which is localized and mediated by actors. Latour's network of actors includes hybrids, and therefore will always be sociotechnical (Latour, 2006).

The network itself is understood by the author of the theory as a characteristic of interaction, the logic of which can be understood if we accept the new ontological foundations of society. "To be" in society is now not the same as "to exist". The first means to act, to interact: "Objects are 'derivatives' of some stable sets or relations" (Latour, 2006: 223).

Researchers call the integration of the ontology of social and technical (natural) existence, which was done by introducing and substantiating the concept of hybrid and actor, the undoubted advantage of Latour's theory. Thus, it removes the subject-object set, thereby overcoming the problem of reducing society and technology to one of the bases. In addition, his network principle of organization of society can be applied not only to the present, but also to all social history, because action is a key characteristic of the actor and is much broader than communication in the concept of Castells.

According to $\mathrm{V}$. Vasilkova, B. Latour's theory very productively uses the cognitive potential of the network metaphor for conceptual construction. Because his social actor creates the "network fabric", building connections and relationships of varying degrees of intensity. (Allusions to understanding of creativity as weaving in the postmodern (and hermeneutic) tradition immediately appear. The words "text" and "textile" are related, and according to the laws of superimposition of meanings in the metaphor it turns out that a person creates text as fabric) (Vasilkova, 2012). For him, "network" is a more flexible concept than "system", it is more historical than "structure", more empirical than "complexity" (Latour, 2006: 141). With its help, he believes, it is possible to describe the hybridity and confusion of life. It has different connotations of the metaphor of the network, including "macrame as a rarefied network": 
each network is rarefied and empty, fragile and heterogeneous, and strengthens only when it expands (Latour, 2006: 34). Due to its cognitive flexibility, this concept like Ariadne's thread combines nature and society, things and knowledge in the description of phenomena that are marginal, multilayered, integrative in nature - that is, those that can only be really interesting to researchers of a new type. The subject of study in this case - "... not things-inthemselves, but how these things are involved in our communities and our subjects. We are talking not about instrumental thinking, but about the very matter of our societies" (Latour, 2006: 62).

In Latour's ideas, the network itself as a metaphor is presented not only through the use of natural-philosophic analogies and terms - for example, such as entelechy, monad and others. Even the structuring of the network appears as the birth of space from chaos. The function of chaos is performed by "background" and "plasma". The background in Latour's sense is something that has not become the focus of consideration (things, installations, laboratories, operations, etc.), but at the same time is a necessary condition for a new discovery. The background can be constructed ("reassembled") by hands and intellect of the scientists: the expansion of the network is also the construction of the material background by building new equivalences. Plasma (or the void between the "threads of the network") is something that is not noticeable in the background, something that is not structured, but potentially it is plasma that allows both "reassembling" a new background and emerging new phenomena in the foreground. Without it, life becomes an established movement in existing ways. Thus, Latour's chaos has the same ambivalent nature in terms of structuring as mythological chaos (as well as dissipative chaos, studied in works on the self-organization of complex systems).

Thus, the image of the social world as a whole appears in B. Latour's theory as a multidimensional and multilevel process of birth, consolidation and death of networks, the struggle of networks for influence. Creation (testing of forces) takes place both within the network and between networks, those networks that are able to gather more actants around themselves win. In this case, any activity (not only scientific) is a collision of networks decorated in recognizable outlines (Latour, 2006: 32). In other words, the network description covers both micro- and macrolevel processes of social life.

The network is understood by him not as a stable structure, but as processes that are continuously constructed, and the formation of connections and their testing. It is very significant that in one of his works Latour is very critical of the fact that in contemporary social cognition it has become almost axiomatic to understand the network as the World Wide Web on the model of the Internet. If the main thing in the network is NOT nodes and structures, but continuous work on the formation of connections and equivalences between network nodes, then the term "network" can be considered unsuccessful, more accurate would be, according to Latour, the term "worknet", which fixes this work on creating network. Actually, Latour's network can exist only in the course of self-construction, "connection and weaving".

The idea of multidimensionality of social construction proved by $\mathrm{B}$. Latour gives grounds for considering the metaphor of the network in the processes of creation and social construction at not only ontological but also epistemological level, i.e. at the level of the process of constructing network as a subject of research.
We have already written above about the ability of metaphor to establish relationships and correlations between theories that take into account different aspects or perspectives of the object - in other words, to construct nodes at the intersection of thematic relationships. In the methodology of social cognition, such a role is played by metatheory, which combines ways of structuring and substantiating knowledge about society, as well as the logical correlation of the main elements that can be analyzed. That is, metatheory analyzes the research strategies, their logical formalization - the properties of derivation, assumptions and consistencies of axioms, patterns of meaning and development of concepts within a subject knowledge. In particular, such theory is the theory by R. Haeussling, who in the conceptual work "Contexts and perspectives of network theory" proposes to build a theory of the network as a network. His argument can be reduced to three points:

1) "flexibility, dynamism and open borders" (Haeussling, 2003) allow network theory to describe the dynamics and variability of society from a constructivist standpoint. While the classical systems theory ( $T$. Parsons) was adapted to describe order and stability, to describe generalized structures based on the rationality of society, the network theory has the means to describe the dynamics and variability. This flexibility is given primarily by the constructivist nature of network theory: it is about flexibility in determining what is an element of the network and what is not; thus, the components of the network can change rapidly over time;

2) network theory is able to be "connected" with any other theories on the principle of fractal (reproduction of the elements of the whole on the principles of selfsimilarity). The "building of theory", in Haeussling's view, arises from the interweaving of theoretical "cores" (Haeussling, 2003). When very heterogeneous theoretical positions are integrated, the main attention should be paid to synchronization and combination of different positions, the tools for which are given by the network theory. Moreover, the metatheoretical scale expands the subject of research, which creates more intense interpretive connections (compared to more local theoretical combinations).

3 ) network theory has no ideological coloring, as it aims to study the structure of society. Scientists of different views, from neo-Marxist to neoliberal, turn to this conceptual scheme. Following the fractal logic of constructing network theory, the scientist concludes that it can acquire a certain worldview orientation on the basis of which it is combined with "modular" groups of theories. Thus, each new structural configuration enriches the network metatheory.

\section{Conclusions}

The analysis revealed the multifaceted role of metaphor in the formation of a network society. Firstly, as a result of a brief analysis of the research that became the foundation of network theory - by K. Durkheim, R. Collins, G. Simmel, G. Deleuze and F. Guattari - we found that researchers have marked a new understanding of social reality through metaphor (as a comparison of the incomprehensible with the understandable), introducing into its characteristics such concepts as ritual, rhizome to emphasize the system, heterogeneity, multiplicity, simultaneity and continuity of localized organizations. That is, metaphors contributed to the formation of the methodological apparatus and even the very name of the theoretical construction which was substantiated - the network society. Secondly, it is a logical framework of societal concepts - 
and this is evidenced by the study of F. Capra, who argued that the change of paradigms of thinking in science was accompanied by a change in basic metaphors. Thirdly, the metaphor is productive in further social construction, because it, as convincingly proved by $\mathrm{B}$. Latour, creates a "network fabric" and builds connections and relationships of different levels and degrees of intensity.

The multilevel and multidimensionality of such connections determines the involvement of metaphors in the processes of social construction not only at the ontological but also at the epistemological level, i.e. at the level of the process of constructing network as a subject of research. In particular, such theory is the theory by R. Haeussling, who argues that network theory can serve as a methodological basis for many other social theories, and proposes its further construction as a kind of network, which once again emphasized the accuracy of metaphorical comparison in the formation of a new type of knowledge.

\section{REFERENCES}

Bauman, Z. (2008). Tekuchaya sovremennost (translat. from English). St.Petersburg: Piter, 240 p. (In Russian)

Capra, F. (2002). Pautina zhizni: Novoye nauchnoye ponimaniye zhivykh sistem. Moscow: Gelios. Retrieved from http:// awake.kiev.ua/system/kapra.htm (In Russian).

Collins, R. (2002). Sotsiologiya filosofiy: globalnaya teoriya intellektualnogo izmeneniya (translat. from English). Novosibirsk. (In Russian).
Collins, R. (2009). Chetyrie sotsiologicheskikh traditsii (translat. from English). Moscow, 320 p. (In Russian)

Deleuze, J. \& Guattari, F. (2010). Tysiacha plato. Kapitalizm i shizofreniya (translat. from English). Yekaterinburg, 895 p. (In Russian)

Durkheim, E. (1954). The elementary Forms of the Religions Life. Glencoe, P. 230-231.

Haeussling, R. (2003). Sotsiologicheskiye esse po osnovnym aspektam setevoy teorii (translat. from English). Moscow, 192 p. (In Russian)

Lakoff, J. \& Johnson, M. (2004). Metafory, kotorymi my zhivem. (translat. from English). Moscow: Yeditorial URSS, 256 p. (In Russian).

Latour, B. (2006). Novogo vremeni ne bylo. Esse po simmetrichnoy antropologii (translat. from Franch). St.Petersburg: Izd-vo Yevrop. un-ta v S.-Peterburge, 240 p. (In Russian)

Simmel, G. (1996). Kak vozmozhno obshchestvo? (translat. from English). In: Izbrannoye. Vol.2. Moscow. 607 p. (In Russian)

Sivokon, A.S. (2016). Set: ot metafory k ontologicheskoy konstante. Izvestiia Saratovskogo universiteta. Seriia Filosofiya. Psikhologiya. Pedagogika. 1. Retrieved from https://cyberleninka.$\mathrm{ru} /$ article/n/set-ot-metafory-k-ontologicheskoy-konstante (In Russian)

Vasilkova, V. V. (2012). Seti v sotsialnom poznanii: ot metafory $\mathrm{k}$ metateorii. Zhurnal sotsiologii i sotsialnoy antropologii. № 5 (15). Retrieved from https://cyberleninka.ru/article/n/seti-vsotsialnom-poznanii-ot-metafory-k-metateorii (In Russian).

\author{
Марія Шніцер, \\ Ужгородський національний університет (м. Ужсгород, Україна) \\ e-mail: mariya.shnitser@uzhnu.edu.ua,ORCID 0000-0003-2781-3928
}

\title{
МЕТАФОРА ЯК ЧИННИК РОЗВИТКУ МЕРЕЖЕВОГО СУСПІЛЬСТВА
}

Показано формування методологічного апарату мережевої теорії і досліджено роль метафори в суспільстві мережі, яка полягає в тому, щоб ідентифікувати зміни реальності і появу нового знання або ж нового варіанту знання. Визначено, що завдяки метафорам змінилася парадигма опису сучасного суспільства, яке характеризують тепер як "мережу" або ж "павутину", "плинне", "динамічне", "нерівномірне" тощо. Найбільш відомими спробами такого описує концепція нової соціальності З. Баумана та акторно-мережева теорія Б. Латура. Остання дозволяє розглядати метафору на гносеологічному рівні пізнання, тобто в процесах соціального конструювання. У цьому випадку за допомогою метафори вибудовуються різного роду метатеорії, що об'єднують способи обґрунтування та структурування знання про суспільство, а також визначають логічну співвіднесеність основних елементів аналізу. В якості ілюстрації таких можливостей метафори наведено аналіз мережевої концепції Р. Гослінга.

Ключові слова: мережева теорія; суспільство мережі; метафрора; метатеорії.

(C) Maria Schnitzer

Надійшла до редакції: 27.12.2019

Прийнята до друку: 22.01.2020 